\title{
The Customer Flow in Chinese Audit Market after SEC Punishment
}

\author{
Longyuan $\operatorname{Sun}^{1} \&$ Xiaohui $\mathrm{Li}^{1}$ \\ ${ }^{1}$ School of Accounting, Central University of Finance and Economics, China \\ Correspondence: Longyuan Sun, School of Accounting, Central University of Finance and Economics, China. \\ E-mail: Sun18317212963@163.com
}

Received: March 28, 2018

doi:10.5539/ijbm.v13n12p193
Accepted: May 20, 2018

Online Published: November 20, 2018

\begin{abstract}
Based on the situation of customers change of the 27 accounting firms punished by China Securities Regulatory Commission (CSRC) in the capital market of China from 1999 to 2016, this paper found the CSRC punishment will cause those clients requiring high financial statement quality to change firm. However, the customers caring more about audit discount and long-term cooperation relationship with auditors will choose to stay. This shows that the intimate relationship between auditors and customers as well as audit cost discount can increase Switching Cost, thus offsetting "Signaling" effect and slowing the customer churn from firm which already received administrative penalty. However, the regulation does not change the fact that the financial report quality of remaining customers is not high.
\end{abstract}

Keywords: auditor - customer relationship, replacement cost, signaling effect, CSRC penalty

\section{Introduction}

Since 1999, the China Securities Regulatory Commission (CSRC) has imposed penalties on several accounting firms, including Reanda and Baker Tilly. Foreign studies have shown that, after their firms are punished, large number of clients will choose new and unpunished firms instead of their original firm. The bankruptcy of Arthur Andersen is the best example. However, in China's capital market, we observed that despite some accounting firms have been punished many times, they are still expanding and also staying at a high level in top 100 list released by the Chinese Association of Certified Public Accountants. Based on this phenomenon, some people think that China's capital market system is far from perfectness and the administrative punishment is not able to work well; others argue that this is due to some factors weakening the firm's customer loss. So in China's capital market, is the administrative penalty of CSRC effective? Are the clients intended to change their office for administrative penalty? If the customer does not tend to change the firm, what are the factors infecting customer loss? Besides, based on the "Signaling Theory", firms getting a penalty can not guarantee customers the authenticity of financial report and will lead to customers loss, which is called "Signaling" effect. However, some scholars in China pointed out that the "Signaling" effect doesn't work well in China's capital market. So is the "Signaling" effect able to work well in China? What factors affect the performance of the "Signaling" effect? These topics mentioned above are the subjects of this paper.

Using the accounting firms which received penalty from 1999 to 2016 in China's capital market as research objects and their A-share listed company clients as sample, this paper aims to explore whether customers tend to abandon the original accounting firm after the firm is punished by CSRC by comparing the customer churn and preserving conditions before and after CSRC punishment, and then discusses whether "Signaling Theory" can fulfill its function in China capital market. The results show that in the capital market of China, even though the firms receive CSRC punishment, customers tend not to change, which seems that "Signaling" effect has no function. But further study shows that the long-term cooperation relationship between the auditors and customers and audit fee discount will enhance the cost of changing firm, which we call Switching Cost, thus adjusting "Signaling" effect. But this cannot change the fact that the left customers' financial reporting quality is still not high.

This paper makes three contribution. Firstly, it is the regulating effect of Switching Cost on "Signaling" effect decides whether the clients will change their firm. This will help to explain why previous study have no unified conclusion for "whether administrative penalty will lead to customer change and figures out the internal mechanism of the corporation decisions for changing firms. This paper also enriches the "Signaling Theory" 
from the perspective of factors affecting it. Secondly, our study shows that the regulation of capital market in China and is not invalid, but regulatory authorities need to make more efforts to make it more significant than the adjustment of Switching Cost. Only by doing this can the regulation can be more effective. Thirdly, our study reveals two important factors affecting Switching Cost: the audit fees and auditor-customer relationship, proving that in the current environment, audit fees and the auditor-customer relationship make effect on the firm's extension and customer retention.

\section{Literature Review}

\subsection{The "Signaling" Effect}

We use "Signaling Theory" to explain the signal transmission problems between the accounting firms and the investors. In the capital market, information asymmetry exists between the provider (accounting firm) and the demand-er (investor, social public and company) of audit service. In order to avoid adverse selection and achieve Pareto Optimal of transaction, reputable firms become a dominant sign to send effective signals to the demand-er of the audit service. Paul and Tim (1986) said that larger firms have high industry expertise and good reputation and the annual report audited by those firms are more likely to be believed and accepted by the public. So firms intending to issue shares and bonds will hire these firms so as to transmit positive signals that their operation performance is real and trustworthy to the public under the help of the expertise and reputation. The same is the study of Beatty (1989). But when the firms are fined by the regulator (CSRC, the PCAOB, etc.), the credibility of auditing reports issued are reduced, thus losing the function to pass positive signals to the society. As a result, the clients of those firms are more inclined to leave and choose another reputable firm (Wilson \& Grimland, 1990; Abbott, 2013; Wang Bing, 2013). And the companies with the stronger power to attract investment (Barton, 2005), lower level of earnings management (Chen \& Chou, 2008; Li Xiaohui et al., 2016), better corporate governance (Chaney \& Philipich, 2002; Asthana et al., 2010) are more likely to change new firms after the original have been punished. That is because these customers owning characteristics mentioned above need more reputable firms to prove the reliability of their good operating conditions, while discredited firm are obviously unable to do this.

\subsection{The Switching Cost}

In reality, when making decision to change the original punished firms, the customers take the service content and charge fee of firm, term of cooperation between client and auditor and other factors into consideration. These will bring "potential value", increasing the difficulty of changing firm, thus influencing the customers' decision for changing firms. These factors owning "potential values" and affecting the changing decision of customers are collectively known as "Switching Cost".

Based on the punishment announcement of CSRC, a Chinese scholar named Liu Feng found that except Zhong Tianqin whose business license are revoked, the customer number of other firms still owning licenses have no big difference. Similarly, another Chinese scholar named Liu Xiaoxia found that companies with a high degree of ownership concentration were not inclined to change after the CSRC punishment. And then, using the fraud of four companies from 2010 to 2013 , Chinese scholars like Ye Fan found that customer churn is not obvious after the four firms are punished. Other research finds that whether the firm provides clients with audit opinions conforming to the requirement of customers (Chow, 1982; Clive, 2010) and excessive audit fee discount (DeAngelo, 1981; Stewart, 2016) may be important factors for the companies when choosing accounting firms. And if there is a long-term relationship between the auditor and the client (Chow, 2002; Liu Feng, 2002; Xue Shuang, 2013), the human value of this relationship will also increase the cost of changing auditors and reduce changing tendency. The study mentioned above all show that whether in reality or in theory, a firm is punished or not is not the only factor clients consider. The fee discount, the "auditor - customer" relationship and other factors will increase the Switching Cost and adjust the firm changing decision.

\subsection{Comments and Opportunities}

In China's capital market, CSRC punishment will lead customers to abandoning the original firm and choosing a new one, but Switching Cost will influence the changing decision of customers. Then, Is the "Signaling" effect more remarkable or the Switching Cost effect? This paper firstly study whether customer tend to leave after their firm has been punished by CSRC, and then whether "Signaling" effect can work well in China's capital market; Secondly, this paper studies the adjustment function of Switching Cost brought by audit discount and "auditor-customer" relationship on "Signaling" effect; finally, this paper studies the financial statements quality change of remaining customers and lost customers after the punishment, revealing the real consequences of such adjustment function. The study will help people understand the phenomenon in which customers will increase instead of decreasing after their firms are punished by CSRC and clarify which effect is more significant 
between the "Signaling" and the Switching Cost in the capital market in China.

\section{Hypothesis and Theoretical Construction}

\subsection{Administrative Penalty and "Signaling" Effect}

Existing research shows that, the company will hire a reputable firm for financing or issuing shares (Paul \& Tim, 1986), and administrative punishment would damage firm reputation, resulting in customers loss (Wilson \& Grimland, 1990). But research of Chinese scholars like Wu Xi, Liu Feng and Ye Fan show that Chinese market is not sensitive to the reputation, the damaged reputation caused by the CSRC on firms and involved auditors will not directly reduce the firm's market share and quasi rent income. Namely, in China, "Signaling" effect does not work very well. Besides, although Reanda and Baker Tilly have been punished in recent years, they still have many customers and stay at a high level in "top 100 accounting firms" list released by Chinese Association of Certified Public Accountants. These phenomena show that in such a competitive "lemon" market in China, the "Signaling" effect of administrative penalty is not significant. After the firm is punished by CSRC, customers tend not to change. Accordingly, we propose hypothesis 1:

H1: If the firm is punished by the CSRC, the client is not inclined to change the firm.

\subsection{The "Auditor - Customer" Relationship}

Based on the fact that Zhong Tianqin was revoked its business license in 2001 by CSRC, some Chinese scholars study the flow direction of its customers. The results found that although most customers choose to leave, there are still a third of the customers choosing the original audit team to undertake the audit work of annual report in the following year, which preliminary show that the auditor-customer relationship can affect the customer's firm choice. A Chinese scholar named Xue Shuang shows that in the process of cooperation with auditors, customers will have "exclusiveness cost" for the auditor. For example, they will spend money, time and energy on the process of the communication with their auditors. And in order to get a reasonable auditing opinion, customers will allow the auditor to get to know the operating situation of the company, the financial system and financial reporting process, forming the so-called "audit support cost". In addition, the personal relationship between CPA and customers is also the proprietary investment between them. The friendship between the original CPA and the customer can not be transferred and inherited through market. In such a "Guanxi" society in china, this kind of "exclusiveness cost" or "audit support cost" is particularly important. Accordingly, we conclude that the audit support costs and "proprietary investment" brought by the longer "auditor - customer" relationship will significantly enhance the Switching cost of customer, which will be more significant than "Signaling" effect brought by the punishment. If there is a longer cooperation relationship between the customer and the firm, even if the firm was fined by the CSRC, the customer will choose to continue to hire it when considering the "audit support cost" and "exclusive investment" brought by these relationships. Therefore, we propose hypothesis 2 :

H2: If the firm is punished by the CSRC, the client who has a longer relationship with involved auditor is not inclined to change the firm.

\subsection{The Audit Fee Discount}

DeAngelo (1981) is the first person to propose the low-balling theory, and believe that accounting firms would attract customers by offering discount on audit fees. Relevant research shows that the pursuit of low audit cost is an important factor influencing the decision of customer for firm selection. Small accounting firms can often expand their market share with low cost advantages in the competition with large firm (Healy \& Lys, 1986; Chen, $\mathrm{Su}, \& \mathrm{Wu}, 2010)$. Therefore we conclude that after the CSRC punishment, firms emphasizing on reducing audit cost is more likely to adopt cost discount strategy to attract customers. And as the reputable firm will not reduce the audit fee, and this cost discount will significantly increase Switching Cost, its effect will be more significant than the "Signaling" effect brought by punishment. Accordingly, we propose Hypothesis 3:

H3: After the firm is punished by CSRC, the audit cost of remaining customers will be significantly reduced.

\subsection{The Quality of the Financial Statements of Lost Customers}

From the point of Signaling Theory, Paul and Tim (1986) found that in IPO or SEO, the company may dismiss the original firm which has undertaken its audit work for many years and choose another one with higher audit quality and better reputation, so as to show investors the signal that they financial information it disclosed is high and reliable, thereby making it easy to raise capital from capital market. From the perspective of the financing cost, if the company continues to engage with the firm which received punishment, the difficulty of raising capital will be much higher. And this is one of the reasons why customers dismiss Arthur Andersen after the outbreak of Enron Event. Therefore, although the "auditor-customer" relationship and audit discount will 
increase the Switching Cost after CSRC punishment, "Signaling" effect will be more significant if the customer cared more about the service credibility provided by accounting firm. Therefore, we propose Hypothesis 4:

H4: If the firm is punished by the CSRC, the customers with higher quality of financial statements will choose to change.

Figure 1 describes the theoretical framework of our study in detail. On the basis of previous study, we need to validate: after the firm received CSRC penalty, customers usually tend to abandon their original firms based on the "Signaling" effect. But if considered the Switching Cost influenced by the close "auditor-customer" relationship and audit fee discount, the customers will tend not to change, but the financial reporting quality of remaining customers is not high.

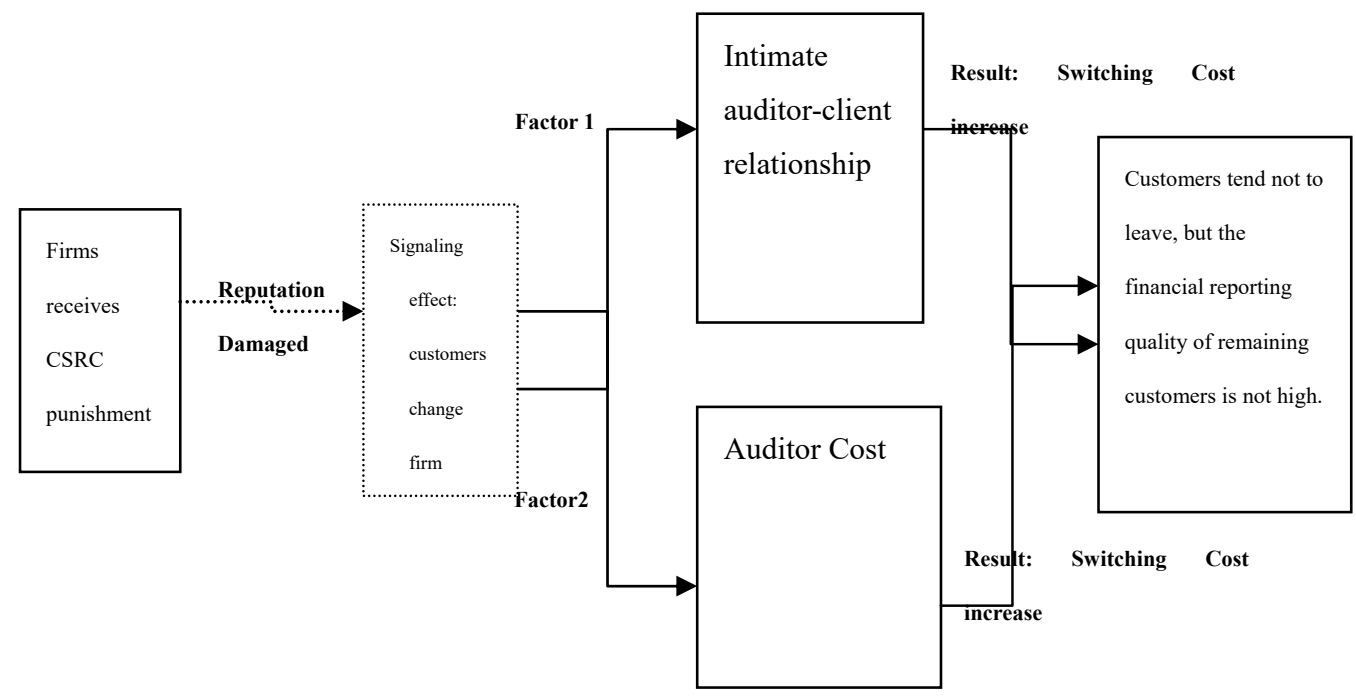

Figure 1. Theoretical model construction diagram

\section{Research Design}

Using the accounting firms punished by CSRC in China's Capital market from 1999 to2016 as the sample group, and firms not punished as the control group, this paper explores the change of customer number and financial reporting quality of punished firms having received penalty to demonstrate our conclusion with the customer data of their A-share listed companies from 1997 to 2016 and the method of DID. The following is the research design.

\subsection{Sample Collection and Screening Process}

Since 1999, total 45 firms have been punished by CSRC. As the annual report of 2017 has not been reported, we will keep the data until 2016. And as many firms have undergone a name variation, cancellation and a series of changes since 1999, we are unable to track and observe the customers change of these firms. So we eliminate firms which have merged or written off after the first year of CSRC punishment, thus remaining 27 firms. In the 27 firms, 11 of which experienced name variation. In order to eliminate its impact, we add the client sample after the name variation to the client sample before name change. At the same time, we did shrink tail handle of continuous variables respectively in $5 \%$ and $95 \%$ in order to eliminate the extreme value. The data of customer financial characteristics is from the Wind database and CSMAR database.

We select the 27 firms as the sample group, and select the customer data of the A-share listed companies in the two years before and after punishment to test our hypotheses.

Then, we define control group based on the average total assets and client number of the punishment firms in the first two years before punishment. We selected 27 alternative accounting firms whose assets and clients number are no longer bigger or smaller than the $20 \%$ of punished firms and are never punished by CSRC and use the customer data of their A-share listed companies data as the control group.

We define a variable Time as the date of punishment, defining Time $=1$ as the first stage after punishment, Time $=-1$ as the first stage before punishment. So from Time $=-2$ to Time $=2$, the total customer sample is 4022 in both the sample group and control group. Of which 2048 is from sample group and 1974 is from control group. 
In order to better explain the change of customer, we divide the customer into two categories:

1. Remaining customer: the customers stay in the firm all the time during two years before and after the punishment of the firm, which totally were 3812, among which 482 companies were in the sample group, with a total of 1962 data; 445 customers were in the control group, totally 1850 data.

2. Lost customer: define the variable Switch $=0$. If a customer exists in the previous period, and change firm in the next period, Switch value will be marked as 1, totally 210 data Among them, there were 86 changed customers in the sample group and 124 in the control group.

\subsection{Model and Variable Settings}

To test H1, we design the following model previous studies so as to study the changes of clients after the CSRC punishment:

Switch $_{i, t}=\alpha_{0}+\alpha_{1}$ Post $+\alpha_{2}$ Punish $+\alpha_{3}$ Post $^{*}$ Punish $+\alpha_{4}$ Size $_{i, t}+\alpha_{5}$ Lev $_{i, t}+\alpha_{6}$ ROA $A_{i, t}++\alpha_{7}$ Loss $_{i, t}+\alpha_{8}$ Growth $_{i, t}+\alpha_{9}$ CFO $_{i, t}+\alpha_{1}$ ${ }_{0}$ BiglO $_{i, t}+\alpha_{11}$ Opinion $_{i, t}+\alpha_{12}$ Mgtch $_{i, t}+\alpha_{13}$ Dmsame $_{i, t}+\alpha_{14}$ Age $_{i, t}+\alpha_{15}$ Issue $_{i, t}+\sum$ Indudum $+\sum$ Timedum $+u_{0}$

This model adopts the Probit regression to estimate coefficient, using time instead of year dummy. If $\alpha_{3}$ is positive and significant, the customers of punished firm are more likely tend to change firm after the CSRC issued the announcement. Conversely, it indicates that it does not tend to change. When we verify $\mathrm{H} 2$ and $\mathrm{H} 4$, we add cross multiplication to analyze it.

To verify H2, we add Tenure to the model (1) for regression analysis:

Switch $_{i, t}=\beta_{0}+\beta_{1}$ Post $+\beta_{2}$ Punish $+\beta_{3}$ Post $*$ Puinsh $+\beta_{4}$ Tenure $+\beta_{5}$ Tenure $*$ Post $*$ Punish $+\beta_{6}$ Size $_{i, t}+\beta_{7}$ Lev $_{i, t}+\beta_{8}$ ROA $A_{i, t}+\beta_{9}$

Loss $_{i, t}+\beta_{10}$ Growth $_{i, t}+\beta_{11}$ CFO $_{i,}+\beta_{12}$ Bigl0 $_{i, t}+\beta_{13}$ Opinion $_{i, t}+\beta_{14}$ Mgtch $_{i, t}+\beta_{15}$ Dmsame $_{i, t}+\beta_{16}$ Age $_{i, t}+\beta_{17}$ Issue $_{i, t}+\sum$ Indud $u m+\sum$ Timedum $+\varepsilon_{0}$

In model (2), Tenure refers to the cooperation time of the auditor in the two auditors whose corporation time with auditors is longer. If $\beta_{5}$ is positive and significant, it indicates that the increased Switching Cost brought by the "auditor-customer" relationship will accelerate the change, otherwise the relationship will slow down the customer's change.

When verifying $\mathrm{H} 3$, we replace the dependent variable with the natural log fee of audit fee Lnfee, and the sample will be reduced to remaining customers. According to the article of He Weifeng and Liu Wei (2015), the design model is as follows:

$$
\begin{aligned}
& \text { Lnfee }_{i, t}=\gamma_{0}+\gamma_{1} \text { Post }+\gamma_{2} \text { Punish }+\gamma_{3} \text { Post }^{*} \text { Punish } \gamma_{4} \text { Size }_{i, t}+\gamma_{5} \text { Lev }_{i, t}+\gamma_{6} \text { ROA }, t+\gamma_{7} \text { Loss }_{i, t}+\gamma_{8} \text { Growth }_{i, t}+\gamma_{9} \text { CFO }_{i,}+\gamma_{10} \text { Bigl } \\
& 0_{i, t}+\gamma_{11} \text { Opinion }_{i, t}+\gamma_{12} I_{i, t}+\gamma_{13} \text { West }_{i, t}+\gamma_{14} \text { Mid }_{i, t}+\sum \text { Indudum }+\sum \text { Timedum }+\varepsilon_{0}
\end{aligned}
$$

Table 1 Definition and interpretation of variables

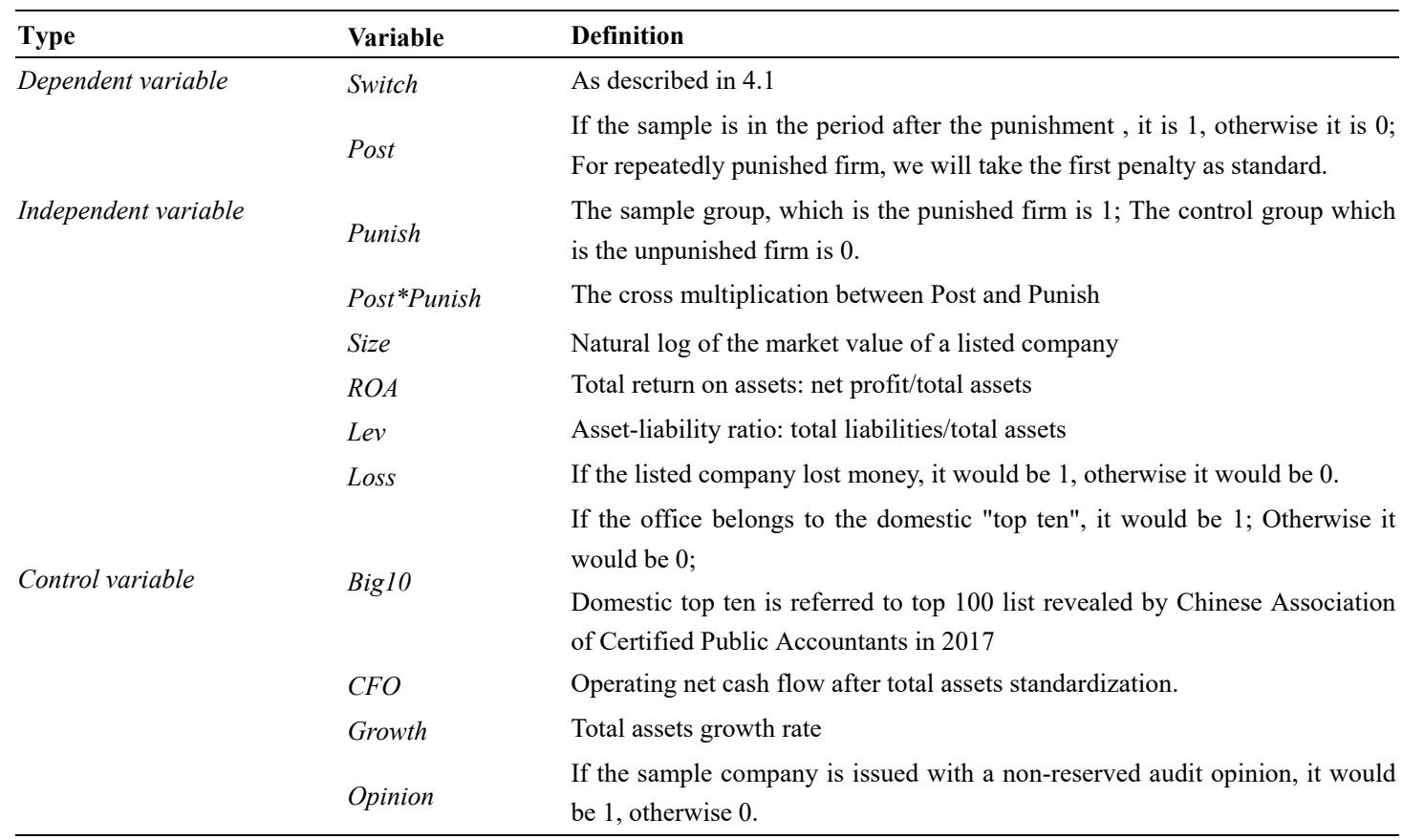




$\begin{array}{ll}\text { Mgtch } & \begin{array}{l}\text { If the chairman or general manager of the listed company has changed, it is } \\ 1, \text { otherwise } 0 .\end{array} \\ \text { Dimsame } & \begin{array}{l}\text { If the chairman or general manager of the listed company is the same person, } \\ \text { it is } 1 \text {, otherwise } 0 . \\ \text { Age }\end{array} \\ \text { Issue } & \text { The time from the company's listing } \\ \text { Indudum } & \text { otherwise } 0 . \\ \text { Timedum } & \text { Industry dummy variable } \\ \end{array}$

The $I R$ is enterprise business complexity, which is the sum of accounts receivable and inventory divided by total asset measurement. West and Mid is registered place of listed company. If the listed companies are registered in the west provinces in China, the West is 1 , otherwise 0 . If the listed companies are registered in middle provinces in China, the Mid is 1, otherwise 0; For the rest places, West and Mid are both 0 .We mainly observed the coefficient of $\gamma_{3}$. If the coefficient of $\gamma_{3}$ is negative, it shows that after CSRC issued the punishment of firm, the audit fees of remaining customer dropping significantly, namely the low audit fees would increase Switching cost, otherwise we cannot prove our conclusion.

To verify the H4, we set sample into the two years after punished, and samples reduced into the lost customer and remaining customer of sample group and control group just in the two years after CSRC punishment. Based on the researches carried by scholars before, the model (4) is constructed:

$$
\begin{aligned}
& |D A|_{i, t}=\theta_{0}+\theta_{1} \text { Switch }+\theta_{2} \text { Punish }+\theta_{3} \text { Switch } * \text { Punish }+\theta_{4} \text { Size }_{i, t}+\theta_{5} \text { Lev }_{i, t}+\theta_{6} \text { ROA }_{, t}++\theta_{7} \text { Loss }_{i, t}+\theta_{8} \text { Growth }_{i, t}+\theta_{9} \text { CFO } O_{i,}+\theta \\
& { }_{10} \mathrm{Age}_{i, t}+\theta_{11} \text { EM }_{i, t}+\theta_{12} \text { Quick }_{i, t}+\theta_{13} \text { Issue }_{i, t}+\sum \text { Indudum }+\sum \text { Timedum } \varepsilon_{0}
\end{aligned}
$$

In addition to the same variables defined in Table $1, E M$ is the real earnings management level. When the $R O A$ of an enterprise is between 0 and $1, E M=1$, otherwise 0 ; Quick is the liquidity ratio of an enterprise, which is defined as current assets divided by current liabilities. We focus on the coefficient of $\theta_{3}$, if it is positive, the financial statements quality of lost customers is significantly lower than that of remaining customers; On the contrary, it indicates that the quality of the financial statements of the changed customers is significantly higher than that of the customer retention.

\section{The Empirical Analysis}

\subsection{Administrative Penalty and "Signaling" Effect}

Firstly, we conducted a descriptive analysis of the changes of customer's number in the sample group and the control group before and after the punishment.

Table 2. The variation of customer number in sample and control group before and after the punishment

\begin{tabular}{lllll}
\hline Time & -2 & -1 & 1 & 2 \\
\hline Sample group & 21 & 33 & 12 & 20 \\
Control group & 28 & 28 & 23 & 45 \\
\hline
\end{tabular}

As it's shown in Table 2, after the firms of sample group are punished in the first phase, customer number in both the sample group and the control group fall, but the decrease in sample group is greater than the control group. In the second stage after being punished, two groups of firms both experience large-scale customers change, but the change in the control group is greater than the sample group, which preliminary illustrates the customers of punished firm tend not to change firm after the administrative penalty.

As can be seen from Table 3, the coefficient of Post* Punish is negative in two periods before and after penalty, which shows that after CSRC punishment, its customers tend not to change, thus verifying H1.This is consistent with the phenomenon that the "customers will increase instead of decreasing after punishment" after CSRC punishment in China, which basically indicates that the "Signaling" effect does not play a very good role in China's capital market. 
Table 3. The variation of customer number in the two groups before and after punishment

\begin{tabular}{lllll}
\hline Variable & Time $=(-\mathbf{1 , 1})$ & & Time $=(-\mathbf{2}, \mathbf{2})$ & \\
Switch & Coefficient & T-value & 0.128 & T-value \\
\hline Post & -0.078 & -0.51 & -0.002 & 1.08 \\
Punish & 0.114 & 0.81 & $-0.365^{* *}$ & -0.01 \\
Post*Punish & $-0.612^{* *}$ & -2.56 & -0.010 & -2.43 \\
Size & -0.039 & -0.70 & -0.5 & -0.25 \\
Lev & -0.181 & -0.59 & $-2.085^{*}$ & -0.79 \\
ROA & -2.010 & -1.27 & -0.094 & -1.95 \\
Loss & -0.148 & -0.62 & 0.191 & -0.61 \\
Growth & $0.395^{* *}$ & 2.31 & -0.323 & 1.61 \\
CFO & -0.502 & -0.60 & 0.131 & -0.57 \\
Big10 & 0.160 & 1.15 & $0.551^{* * *}$ & 1.42 \\
Opinion & $0.704^{* * *}$ & 3.92 & $0.342^{* * *}$ & 4.46 \\
Mgtch & $0.483^{* * *}$ & 3.70 & 0.001 & 3.81 \\
Dmsame & 0.072 & 0.57 & 0.014 & 0.01 \\
Age & 0.010 & 0.80 & 0.208 & 1.62 \\
Issue & -0.094 & -0.41 & -4.918 & 1.63 \\
cons & -0.846 & -0.71 & Controlled & -0.06 \\
Industry and Year & Controlled & & 0.13 & \\
Pseudo. $R^{2}$ & 0.10 & & 3714 & \\
$N$ & 1940 & & & \\
\hline
\end{tabular}

\subsection{The Adjustment of "Auditor-Customer" Relationship}

From Table 4, we find that after the Tenure is added to the cross multiplication between Post and Punish, the coefficient of Tenure* Post*Punish in the first phase after the punishment is negative but not significant, but the coefficient of the second phase is significantly negative. This shows that relative to the firm no punishment, the longer cooperation relationship between auditor of the punished firm and customer, the less they are inclined to change firm in terms of customers, thus verifying H2. This shows that the longer "auditor-customer" relationship will enhance and increase Switching Cost, which will help retain customers and weaken the function of the "Signaling" effect.

Table 4. The adjustment of auditor tenure on customer churn

\begin{tabular}{|c|c|c|c|c|}
\hline \multirow{2}{*}{$\begin{array}{l}\text { Variable } \\
\text { Switch }\end{array}$} & \multicolumn{2}{|l|}{ Time $=(-1,1)$} & \multicolumn{2}{|l|}{ Time $=(-2,2)$} \\
\hline & Coefficient & T-value & Coefficient & T-value \\
\hline Post & -0.029 & -0.19 & $0.313^{* *}$ & 2.35 \\
\hline Punish & 0.196 & 1.36 & 0.107 & 0.97 \\
\hline Post*Punish & 6.874 & 0.04 & $3.078^{* * *}$ & 5.46 \\
\hline Tenure & $-0.068^{* * *}$ & -3.34 & $-0.204^{* * *}$ & -10.01 \\
\hline Tenure* Post*Punish & -5.709 & -0.03 & $-1.974^{* * *}$ & -5.12 \\
\hline Size & -0.030 & -0.50 & -0.006 & -0.10 \\
\hline Lev & -0.132 & -0.40 & -0.138 & -0.57 \\
\hline ROA & -1.924 & -1.16 & -1.737 & -1.43 \\
\hline Loss & -0.104 & -0.42 & -0.164 & -0.80 \\
\hline Growth & $0.356^{* *}$ & 1.99 & 0.025 & 0.16 \\
\hline Big10 & 0.142 & 0.96 & 0.075 & 0.65 \\
\hline CFO & -0.462 & -0.51 & -0.091 & -0.14 \\
\hline Opinion & $0.688^{* * *}$ & 3.60 & $0.611^{* * *}$ & 4.34 \\
\hline Mgtch & $0.422^{* * *}$ & 3.00 & $0.322^{* * *}$ & 3.05 \\
\hline Dmsame & 0.104 & 0.77 & 0.025 & 0.26 \\
\hline Age & 0.022 & 1.55 & $0.039^{* * *}$ & 3.88 \\
\hline Issue & -0.166 & -0.67 & 0.142 & 0.93 \\
\hline cons & -1.210 & -0.94 & -1.233 & -1.27 \\
\hline Indusrty and Year & Controlled & & Controlled & \\
\hline Pseudo. $\mathrm{R}^{2}$ & 0.21 & & 0.28 & \\
\hline $\mathrm{N}$ & 1940 & & 3714 & \\
\hline
\end{tabular}




\subsection{The Adjustment of Audit Fee}

Since the audit fee data was disclosed since 2006, the sample size is smaller than H2. From the perspective of the regression results of existing data in Table 5, the audit fee is significantly reduced in the two periods after penalty, suggesting that firm reduces the retaining customer's audit fee. Combining with the result of H1, we can see that reduced audit fee can increase the Switching Cost of the customer. This retards customer changes to a certain extent, thus verifying $\mathrm{H} 3$. This also indicates that for some customers, the consideration of audit cost is prior to consideration of audit quality.

Table 5. The variation of audit fees of remaining customers before and after the punishment

\begin{tabular}{lllll}
\hline $\begin{array}{l}\text { Variable } \\
\text { Lnfee }\end{array}$ & $\begin{array}{l}\text { Time=(-1,1) } \\
\text { Coefficient }\end{array}$ & T-value & $\begin{array}{l}\text { Time=(-2,2) } \\
\text { Coefficient }\end{array}$ & T-value \\
\hline Post & 0.026 & 0.86 & 0.024 & 0.90 \\
Punish & $0.058^{* *}$ & 2.22 & $0.059^{* * *}$ & 2.27 \\
Post*Punish & $-0.071^{* *}$ & -1.68 & $-0.074^{* * *}$ & -1.99 \\
Size & $0.322^{* * *}$ & 29.87 & $0.322^{* * *}$ & 36.78 \\
Lev & $0.170^{* * *}$ & 2.89 & $0.144^{* * *}$ & 2.96 \\
ROA & $0.848^{* * *}$ & 2.82 & $0.810^{* * *}$ & 3.31 \\
Loss & 0.034 & 0.78 & 0.056 & 1.58 \\
Growth & -0.052 & -1.49 & -0.022 & -0.78 \\
Big10 & $0.174^{* * *}$ & 6.38 & $0.164^{* * *}$ & 7.22 \\
CFO & 0.003 & 0.02 & 0.034 & 0.26 \\
Opinion & $0.179^{* * *}$ & 4.03 & $0.142^{* * *}$ & 3.81 \\
IR & -0.005 & -0.19 & -0.003 & -0.40 \\
West & $-0.139^{* * *}$ & -5.23 & $-0.130^{* * *}$ & -5.87 \\
Mid & $-0.066^{* * *}$ & -2.65 & $-0.063^{* * *}$ & -3.05 \\
cons & $6.221^{* * *}$ & 27.31 & $6.240^{* * *}$ & 33.55 \\
Industry and Year & Controlled & & Controlled & \\
adj. $R^{2}$ & 0.465 & & 0.475 & \\
$N$ & 1874 & & 2578 & \\
\hline
\end{tabular}

\subsection{The Quality of Financial Statements of Lost Customers and Remaining Customers}

It can be seen that from Table 6, the Switch * Punish coefficient is negative but not significant in the first year after the punishment, but becomes significantly negative in the second year after being punished, which suggests that as time goes on, the quality of financial statements of the lost customers is significantly higher than the remaining customers. And the gap of financial statements quality between the lost customers and remaining customers of the punished firm is larger than the firms without being punished, thus verifying H4. This shows that for the customer demanding high quality financial statements, the "Signaling" effect is significantly more important than the increased Switching Cost brought by "auditor - customer" relationship and the audit fee discount. Therefore, this kind of customer is more inclined to change firm after being punished. 
Table 6. The variation of DA of both remaining and lost customers in the 2 years after the punishment

\begin{tabular}{lllll}
\hline Variable & \multicolumn{2}{l}{ One year after punishment } & \multicolumn{2}{l}{ Two years after punishment } \\
DA & Coefficient & T-value & Coefficient & T-value \\
\hline Switch & 0.003 & 0.14 & $-0.024^{* *}$ & -2.08 \\
Punish & -0.002 & -0.33 & -0.002 & -0.42 \\
Switch*Punish & -0.059 & -1.43 & $-0.049^{* *}$ & -2.40 \\
Size & $-0.013^{* * *}$ & -4.37 & $-0.014^{* * *}$ & -6.82 \\
Lev & $0.088^{* * *}$ & 4.45 & $0.074^{* * *}$ & 5.37 \\
ROA & 0.037 & 0.46 & 0.047 & 0.85 \\
Loss & $0.037^{* * *}$ & 3.00 & $0.025^{* * *}$ & 3.03 \\
CFO & 0.002 & 0.04 & -0.001 & -0.03 \\
Age & 0.002 & 0.28 & 0.001 & 1.22 \\
Growth & $0.067^{* * *}$ & 5.65 & $0.062^{* * *}$ & 8.05 \\
EM & 0.002 & 0.07 & $0.026^{*}$ & 1.70 \\
Quick & $0.005^{* *}$ & 2.03 & 0.002 & 1.51 \\
Issue & 0.011 & 0.98 & $0.012^{*}$ & 1.79 \\
cons & $0.250^{* * *}$ & 3.99 & $0.288^{* * *}$ & 6.63 \\
Industry and Year & Controlled & & Controlled \\
adj. $R^{2}$ & 0.150 & & 0.148 & \\
$N$ & 692 & & 1453 & \\
\hline
\end{tabular}

\section{Further Analysis and Robustness Test}

\subsection{The Test of Audit Opinion of the Customer}

The study was conducted primarily to examine whether the firm made a concession of audit opinion on the client after being punished. We set the variable Opinion, when the customer gets the unmodified audit opinion, it is 0 , otherwise 1. When establishing the model, we found that there was no significant improvement in the number of unmodified audit opinion issued by the punished firms. Thus, we find that firms make concessions mostly in the audit fee level. In the aspect of retarding customer losses caused by the administrative penalty, the effect of low bailing is even more important than the regulation of audit opinion compromise.

\subsection{Robustness Test}

In addition, we conducted the following robustness tests:

Firstly, we used the industry and the annual dummy to shorten the tail of control variable and replace the original shrinkage, and the result was unchanged.

Secondly, we used the manipulative accrued absolute value calculated by modified Jones model to replace $|D A|$ calculated by standard Jones model, and the result was unchanged.

Thirdly, we replaced term variable Tenure as the shorter term of auditor between two signed CPA of listed companies. When the Tenure was introduced into Probit model for regression, the results remained unchanged

Fourthly, we replaced the Probit model with Logit model for regression, and the result was unchanged.

Last but not the least, we replaced the dummy variable of Time with annual variable, and the result was unchanged.

\section{Conclusion}

Using the punished firms by CSRC in China's capital market from 1999 to 2016 and their A-share public customer companies as sample, this paper explores whether customers intend to change firm after the CSRC punishment by observing the situation of remaining customer and lost customer in the two periods before and after penalty. The results show that the customers are not inclined to change after the punishment of the CSRC, indicating that the "Signaling" effect has no function. But, after further study, we found that firm will increase Switching Cost of customers by establishing long-term cooperation relationship between auditor and customers and making audit fee discount, which regulates "Signaling" effect. However, this regulatory effect does not change the fact that the quality of the remaining customer's financial statements is not high.

According to the empirical analysis mentioned above, we believe that after the firm suffered CSRC punishment, customers will make firm changing decision based on the importance of "Signaling" effect and "Switching Cost" 
effect. For those customers who have a low requirement of financial reporting quality and only see the short-term benefits brought by lower audit cost and the "auditors -customer" relationship, the relationship between auditors and customers and audit discount will make Switching Cost effect more significant than "Signaling" effect, so the customer will stay; For those customers owning a higher quality requirements of financial reporting and thinking highly of long-term effect brought by the good reputation, the "Signaling" effect brought by the administrative punishment is more significant than Switching Cost effect, and customers choose to change firm. Therefore, the administrative penalty in China's capital market is not invalid. Because the main market players are not sensitive to reputation and Switching Cost would adjust "Signaling" effect, companies will not tend to abandon their firms after CSRC punishment.

Therefore, from the perspective of regulators, it is necessary to strengthen supervision and improve the punishment mechanism so that the "Signaling" effect can work better. From the perspective of accounting firms, those who relying on reducing the audit cost and making intimated relationship between auditors and customers to keep customers is not wise, and they should take safeguarding the investors interests as own duty and establish good faith to continuously improve its ability to prevent risks in independence, score management, quality control so as to fundamentally retain customers.

\section{References}

Abbott, L. J., Gunny, K., \& Zhang, T. C. (2013). When the PCAOB talks, Who Listens? Evidence from Stakeholder Reaction to GAAP - Deficient PCAOB Inspection Reports of small auditors. Auditing, 32(2), 1-31. http://dx.doi.org/10.2139/ssrn.1266950

Asthana, S. C., Balsam, S., \& Krishnan, J. (2010). Corporate Governance, Audit Firm Reputation, Auditor Switches, and Client Stock Price Reactions: The andersen experience. International Journal of Auditing, 14(3), 274-293. https://doi.org/10.1111/j.1099-1123.2010.00417.x

Barton, J. (2005). Who Cares About Auditor Reputation? Contemporary Accounting Research, 22(3), 549-586. http://dx.doi.org/10.2139/ssrn.436967

Beatty, R. P. (1989). Auditor Reputation and the Pricing of Initial Public Offerings. Accounting Review, 64(4), 693-709. http://dx.doi.org/10.1002/hec.1807

Chaney, P. K., \& Philipich, K. L. (2002). Shredded Reputation: the Cost of Audit Failure. Journal of Accounting Research, 40(4), 1221-1245. https://doi.org/10.1111/1475-679X.00087

Chen, C. J. P., Su, X., \& Wu, X. (2010). Auditor Changes Following a Big4 Merger with a Local Chinese Firm: A Case Study. Auditing A Journal of Practice \& Theory, 29(1), 41-72. https://doi.org/10.2308/aud.2010.29.1.41

Chow, C. W. (1982). The Demand for External Auditing: Size, Debt and Ownership Influences. Accounting Review, 57(2), 272-291. https://doi.org/10.2307/247014

Healy, P., \& Lys, T. (2006). Auditor Changes Following Big Eight Mergers with Non-big Eight Audit Firms. Journal of Accounting \& Public Policy, 5(4), 251-265. https://doi.org/10.1016/0278-4254(86)90022-0

Weber, J., Willenborg, M., \& Zhang, J. (2008). Does Auditor Reputation Matter? The Case of KPMG Germany and COMROAD AG. Journal of Accounting Research, 46(4), 941-972. https://doi.org/10.1111/j.1475-679X.2008.00298.x

Lennox, C. (2000). Do Companies Successfully Engage in Opinion-Shopping? Evidence from the UK. Journal of Accounting \& Economics, 29(3), 321-337. https://doi.org/10.1016/S0165-4101(00)00025-2

Wilson, T., \& Grimlund, R. (1990). An Examination of the Importance of an Auditor's Reputation. Auditing A Journal of Practice \& Theory, 9(2), 43-59.https://doi.org/0278-0380

\section{Copyrights}

Copyright for this article is retained by the author(s), with first publication rights granted to the journal.

This is an open-access article distributed under the terms and conditions of the Creative Commons Attribution license (http://creativecommons.org/licenses/by/4.0/). 